https://doi.org/10.5817/OS2018-3-11

\title{
Slovanský svět: studie na počest ruského polonisty
}

БУДАГОВА, Л. Н. (ред.): Pax latina \& pax orthodoxa: славистические исследования: история, культура, литература: в честь 8о-летия со дня рождения Александра Владимировича Липатова. Москва: Федеральное государственное бюджетное учреждение науки, Институт славяноведения РАН 2017. ISBN 978-5-7576-0406-о.

Brilantně charakterizuje roli Alexandra Lipatova na poli ruské slavistiky, zejména polonistiky, a to v širokém rozsahu od historie přes filozofii k literatuře jeho kolegyně a editorka př́tomného svazku Lidija Budagovová. Sborník, který vychází na počest jeho osmdesátin, shrnuje v podstatě všechny oblasti jeho činnosti. Alexandr Lipatov se narodil v Dněpropetrovsku (nesl jméno místního bolševika Grigorije Petrovského; v rámci dekomunizace Ukrajiny přejmenován roku 2016 ukrajinskou vládou na Dnipro, ale nebylo to poprvé: město od svého založení roku 1776 jako Jekatěrinoslav, třetí hlavní město Ruské říše po Sankt-Petěrburgu a Moskvě, neslo pět pojmenování; dvě další nenabyla oficiálního statutu nebo platila jen krátce) roku 1937, jinak však svůj život spojil s Moskvou, kde studoval na Lomonosovově univerzitě, později také ve Varšavě polonistiku. Nositel vysokých polských vyznamenání a polský akademik učinil polonistiku, studium polské literatury a polsko-ruských vztahů východiskem své vědecké činnosti, nicméně jeho vědecká činnost je rozkročena po celém teritoriu Slovanů západních, jižních a východních: obsah festschriftu tedy odpovídá jeho vědeckému rozpětí, které zahrnuje oba nábožensko-kulturní okruhy slovanského světa. ${ }^{1}$

První oddíl obsahuje studie ruských a dvou polských badatelů, které pokrývají několik problémů ruské a polské historiografie (Stranicy prošlogo i nastojaščšego). Viktorija Močalovovová (Moskva) pojednává ve své studii o postavě Michaila Borisoviče Šejna (asi 1575-1634), představitele staromoskevské šlechty, muže pruského původu, jehož předkové přišli ve 13. století do Velikého Novgorodu. On sám se zúčastnil tažení Borise Godunova proti krymským Tatarům, bránil Smolensk před Poláky a Litevci v těžkém období smuty, slavná byla zvláště obrana Smolenska. I když pak strávil několik let v polském zajetí, později se přesto stal nejbližším spolupracovníkem prvního Romanovce na ruském trůně, znovu bojoval proti Polákům a byl přitom zakladatelem rozsáhlé rozvědné sítě ve východních částech Rzeczi pospolité. Nakonec byl obviněn ze zrady (pravděpodobně neprávem) a na základě bojarských intrik

1 Z jeho prací uvádíme alespoň tyto: Vozniknovenije pol'skogo prosvetitel'skogo romana: problemy nacional'nogo i obščejevropejskogo. Moskva 1974. Formirovanije pol'skogo romana i jevropejskaja literatura: Srednevekov’je. Vozroždenije. Barokko. Moskva 1977. Literatura v krugu šljachetskoj demokratii: (Pozdneje Barokko. Prosveščenije. Predromantizm). Moskva 1993. Słowiańszczyzna-Polska-Rosja: Studia o literaturze i kulturze. Izabelin, 1999. Rosja-Polska: konfrontacja i grawitacja. Literatura. Kultura. Polityka. Torun, 2003. 
popraven. Badatelé dnes řeší rok jeho narození, jeho přesný původ, ale také sporné peripetie jeho vojenské a politické kariéry a hlavně polský a ruský pohled na události smuty a vlády prvních Romanovců. $Z$ hlediska dneška téma více než aktuální.

Valerij Konovalov (Jaroslavl') ve studii Tragedija razorvannoj postepennosti si klade otázku, zda v ruských dějinách bylo nějaké přechodné období. Autor je vidí na konci 16. století, kdy se $\mathrm{v}$ důsledku Petrových reforem mění poměr $\mathrm{k}$ Polsku a degraduje polský vliv v Rusku, jež se definitivně mění v impérium evropského a světového významu; toto osudové rozhodnutí určilo vývoj Ruska na dalších 200 let a přineslo problémy, jež Rusko řeší dodnes. Př́liš nerozumím hodnotovému zaměření stati: tedy tomu, zda Petrovy reformy přinesly Rusku prospěch; jinak řečeno: zda pokračující polský vliv by Rusku přinesl jen samé klady, nebo zda reformy Petra I. vrhly Rusko riskantně na Západ a urychlily jeho vývoj k pozici světové velmoci; všechny tyto kroky jsou ovšem - jako v historii vše - problematické a mají své černobílé konsekvence. Ve sborníku na počest A.Lipatova má analýza konce polského vlivu v Moskvě své klíčové místo.

Marian Broda (Łódź) ve studii o Machiavelim, Kantovi a antinomii současné politické morálky uvažuje o vývoji lidských představ o uspořádání společnosti a sladění individuálních zájmů: na základě Kantovy Kritiky praktického rozumu upozorňuje nejen na nezbytí svobody a lidských práv, ale také na nezbytí nepokládat člověka a lidstvo za cíl, ale podřizovat je nějakému obecnému morálnímu principu. Obecně, ale i v současném světě vidí jako nebezpečí pro občana, právní stát a celkové uspořádání právě nedodržování obecnějších principů, které rozkládají původně křestanský řád: pluralita a svoboda mohou ve svých důsledcích vést $\mathrm{k}$ mnohem monolitnějšímu uspořádání, než jaké bylo před zavedením demokracie.

Marina Smol'janinovová (Moskva) upozorňuje na současné bulharské diskuse o osvobozenecké válce Bulharska v 19. století a na snahu revidovat původní koncepce pojetím jiné okupace (ruské). Ukazuje, že např. N. M. Karamzin v Dějinách ruského státu bulharský národ ani nezmiňuje, což podle autorky dokládá fakt jeho postavení na osmanském Balkáně. Autorka doufá ve vědeckou diskusi o charakteru osvobozenecké války, o povaze bulharsko-tureckých a turecko-ruských vztahů.

Svetlana Fal'kovičová (Moskva) analyzuje sociální aspekt polských ideologických koncepcí konce 18. a poloviny 19. století, jež měly svůj význam nejen ve své době, ale také později za soumraku polské aristokratické revoluce v 6o. letech 19. století. Škoda, že se autorka nezmiňuje o sociálním aspektu polských panslavistických koncepcí počátku 19. století spojených s vládou Alexandra I. a jeho ministra zahraničí Adama Czartoryského. $^{2}$

2 Viz naši studii Frank Vol'man i jego polemiki o panslavizme. In: Panslawizm wczoraj, dziś, jutro. Red. Zofia Chyra-Rolicz i Tomasz Rokosz. Uniwersytet Przyrodniczo-Humanistyczny w Siedlcach, 
Anna Jach (Kraków) nás přenáší takřka do př́tomnosti, když zkoumá události srpnového puče roku 1991 v SSSR jako projev občanské neposlušnosti a ukazuje, že toho nebylo využito $\mathrm{k}$ aktivizaci lidu v novém systému: obě bojující strany byly totiž dědičkami sovětského systému. Jistě by se našly i názory jiné, diferencující povahu událostí, ale na to je ještě asi př́liš brzy.

Druhý oddíl sborníku Vzaimovosprijatije narodov. Kul'turnyje svjazi i kontakty uvádí studie českobudějovického historika Bohumila Jirouška cestě mladého Josefa Kalouska (1838-1915) do bukovinských Černovic (ukraj. Černivcy) v roce 1863. Český historik tuto cestu ukazuje pro budoucí stěžejní postavu české historiografie doslova jako iniciační. Natalia Žakovová píše ve své stati o historii slovanských sjezdů v 19. století, zejména o setkání Slovanů v Sankt-Petěrburgu a Moskvě v roce 1867. Jak je všeobecně známo, byl to důležitý, spíše však demonstrativní krok české politiky a kultury proti rakousko-uherskému vyrovnání, jenž vydal i významné literární plody.

Alla Maškovová (Moskva) analyzuje názory Svetozára Hurbana Vajanského na ruskou literaturu: zvláště zmiňuje Gogola a Turgeněva, Lva Tolstého, méně píše o Dostojevském; k Čechovovi byl Hurban Vajanský značně kritický. Moskevská slovakistka ukazuje jednak na to, že se Hurban Vajanský v řadě věcí mýlil nebo jeho názory byly rozporné, na druhé straně připouští, že odhaloval takříkajíc ze strany, ze zorného úhlu jiné kulturní zkušenosti jiné, méně známé vlastnosti jejich děl (to je zvláště patrné $\mathrm{v}$ př́padě Ivana Turgeměva). Hurban Vajanský jako přesvědčený rusofil vnesl do slovenské literatury ruský realismus a také ruské lexikum, slova, která na Slovensku zdmomácněla a stala se součástí slovní zásoby spisovné slovenštiny - jich má slovenština podstatně více než čeština. Současně slovenský spisovatel kritizoval západní pojetí ruské literatury, zejména satiry N. V. Gogola a kritického pohledu I. S. Turgeněva (podle nich prý podrývají autoritu Ruska jako velmoci): sám se však podobných soudů také dopouštěl, např̀ v př́ipadě Zločinu a trestu.

Vynikající komparativní analýzu přináší studie Zbigniewa Opackého (Gdańsk), jenž ukazuje na kořeny polské nezávislé rusistiky v meziválečném období na dílech Mariana Zdziechowského (1861-1938) a Wacława Lednického (1891-1967), absolventa moskevského gymnázia, Jagellonské univerzity a také Lomonosovovy univerzity a později profesora Harvardovy univerzity a Kalifornské univerzity v Berkeley, kam odešel přes Belgii a Francii na počátku druhé světové války. Jako Poláci (první vlastně dlouho žil i na území autochtonního Ruska nebo Baltie: Sankt-Petěrburg, Dorpat/ /Děrpt/Jur'jev, tedy dnešní Tartu aj., druhý žil v západní Evropě a v USA, oba vyšli prrímo z reality Ruské ŕíše a obnoveného Polska), se dívali na Rusko kriticky a skepticky, stejně jako na jakékoli slovanské scelování - zde zejména Lednicki narazil na odpor

Wydział Humanistyczny, Instytut Nauk Społecznych i Bezpieczeństwa, Instytut Filologii Polskiej i Lingvistyki Stosowanej, Instytut Historii i Stosunków Międzynarodowych, Siedlce 2016, s. 147-160. 
v polemikách Franka Wollmana, jež se týkaly samotné existence pojmu „slovanské literatury" - o tom se však ve stati nedovíme nic.

Jan Bílek (Hradec Králové - Praha) líčí cestu Karla Čapka do Anglie roku 1924 a vznik „pátečníkư“ a zkoumá hypotézu, podle níž právě zde našel pro „pátečníky“ vzor v anglických debatních klubech. Tadeusz Sucharski (Słupsk) demonstruje na pracích Czesława Miłosze o Dostojevském, jak polský básník a publicista chápe ruského romanopisce jako myslitele na pokraji křestanské hereze s rozmytými hranicemi mezi náboženstvím a národní ideou, jenž u filozofů vybojoval Krista jako vůdčí postavu bohonositelů ruské vůle $\mathrm{k}$ moci. Nejsem si jist, zda podstata textů polského básníka není poněkud posunuta oproti pojetí Sucharského, ale i tak jde o typickou autoprojekci umělce do díla jiného umělce.

Oddíl Slovanské literatury uvozuje shrnující stat poblému cizinců v ruské literatuře a postavě polsko-ruského literáta Fadděje (Tadeusze) Bulgarina (Bułharyna). Podnětná je studie Natalie Anaňjevové (Moskva) o polském intertextu v ruské literatuře 19.-21. století, jež nezůstala na povrchu zkoumání stereotypu, ale šla do hloubky a hlavně ukázala na víceapektovost problému, jenž zahrnuje i jazykové prostředky, poetiku, žánrové hledisko aj. Leonid Malcev (Kaliningrad) hledá hamletovský klíč ke dvěma románům: Kráse života (Uroda życia, 1912) Stefana Żeromského (1864-1925) a Rudým štítům (Czerwone tarcze, 1934) Jarosława Iwaszkiewicze (1894-1980).

Irina Adel'gejmová (Moskva) ve fascinující studii „Ovládnutí paměti“. Próza dětí těch, kteř́ přežili, jako akt psychoterapie („Osvojenije pamjati“. Proza detej Vyživšich kak akt psichoterapii) reaguje na klíčovou otázku pokračování nebo uzavření historie holokaustu v dalších generacích přeživších. Ljudmila Širokovová (Moskva) srovnává ve své studii křest̉anské motivy v dílech Vincence Šikuly a Vasilije Šukšina a dochází k závěru, že nejde jen o religiozitu, ale spíše o národní tradice s nimi spojené. Natalija Švedovová (Moskva) analyzuje umělecký překlad ze slovenštiny do ruštiny jako prríklad pohybu mezi vědou a uměním, nap̌r. na překladech Anny Achmatovové z díla Miroslava Válka (1927-1991) Dotyky (1959). Sám tento fakt, byt’ známý, je hodný zaznamenání. Vtipným závěrem svazku je studie Viktora Kosika (Moskva) O radosti života (čes. snad O radosti žaludku) o rituálním rázu jídla u Slovanů.

Poněkud př̀kvapí malá česká účast (dva přispěvatelé se dotýkají českých věcí, jeden rusko-polských), naopak tu převažují ruští slovakisté, resp. slovakistky.

Jubilejní svazek obsahuje sice různorodý materiál, ale ten je scelován společnými motivy rusko-polskými a obecně slovanskými a filozoficko-historickými. Dotýká se delikátních složitostí rusko-polských vztahů, byt̉ obchází jejich nejbolavější místa. Je to svazek jubilejní, a proto není vhodné rozdírat rány, ale sám jubilant k vyjasnění těchto komplikací, konfliktů a kontroverzí nemalou měrou přispěl. Vychoval žáky, kteří snad budou v tomto duchu na obou stranách rusko-polské hranice pokračovat. 


\section{Literatura:}

BUDAGOVA, L. N. (ed): Pax Latina \& Pax Orthodoxa: Slavističeskije issledovanija. Istorija, kul'tura, literatura. V čest' 8o-letija so dnja roždenija Aleksandra Vladimiroviča Lipatova. Moskva: Federal'noje gosudarstvennoje bjudžetnoje učreždenije nauki, Institut slavjanovedenija RAN, 2017. ISBN 978-5-7576-0406-0.

https://doi.org/10.5817/OS2018-3-12

\section{Pamät času si uchová meno a tvár svojho tvorcu}

V kultúrnom a literárnom živote, pri ich dynamike, členitosti, pestrosti aj naliehavosti sa vo vedomí spoločnosti darí predovšetkým tým tvorcom, ktorým sa nimi utvorenými nástrojmi dialógu s ňou z rozličných podnetov venuje výraznejšia, či až sústredená pozornost'. Média, kultúrne akcie, besedy, literárne rozhovory, výstupy tvorivej aktivity, záujem a ich vyhladávanie kultúrnou obcou spôsobujú, že sa o udalosti, jave či tvorivej osobnosti v istom čase a za istých okolností zvýrazňuje fakt, že má zmysel sledovat prejavenie sa a uplatnenie hodnoty v umení, dotvárat prospešnými rozhodnutiami dotyk jedinečnosti s výnimočnostou. Azda aj neželaným následkom, niet o také situácie núdze, sa do úzadia pozornosti, záujmu a zverejňovaných výpovedí o hodnote a šírení tradičnými aj novými prostriedkami kultúrneho a literárneho života dostanú ich dalšie a početné súčasti, lebo sa dostali, vdaka okolnostiam, do ich tieňa.

Panta rei, pohyb času a premeny v ňom naznačujú, že náručie dejín kultúry a literárnej histórie zostávajú otvorené času a jeho obsahom v umení a v literárnovednej tvorbe. Cúdenie podstatného od ostatného, ktorým sa čas obsiahnutý v pamäti spoločnosti a ňou podporovanej a oceňovanej kultúry, zvlášt v pôvodnej a prekladovej umeleckej spisby si osvojuje literárna veda svojimi súčastami, aby vytvorila hodnotovú a javovú zásobnicu pre syntézy, hoci aj tie, ktoré odborná a širšia verejnost̉ pozná vo forme dejín, kompendií, slovníkov či inak.

Dejiny kultúry a dejiny literatúry sa vyrovnávajú s obsahom, jedinečnost̉ou a podstatou literárneho života a literárneho procesu tak, že sa z času a jeho obsahov abstrahujú tie činy a riešenia, ktoré znamenajú - vdaka plynúcemu času, teda vývinu a ním iniciovaným procesom - oporné miesta a také istoty, z ktorých sa odvíjajú úvahy o zmysle, význame a jedinečnosti konkrétneho literárneho procesu, generácie, či konkrétneho genologického komponentu, literárnej estetiky, aby sa zmysluplne udržalo a účinne podporovalo spoločenskými prostriedkami a ich možnostami tvorivého zázemia osobností zapojených do jedinečnosti hodnotového povedomia (národného) kultúrneho spoločenstva a umenia. 